\title{
Assessment of cardiometabolic risk among shift workers in Hungary
}

György Jermendy ${ }^{1 *}$, Judit Nádas ${ }^{1}, \|$ lona Hegyi ${ }^{2}$, István Vasas ${ }^{2}$ and Tibor Hidvégi ${ }^{3}$

\begin{abstract}
Aim: Shift workers may be at risk of different diseases. In order to assess cardiometabolic risk in shift workers, a cross-sectional study was performed among active workers.

Methods: A total of 481 workers (121 men, 360 women) were investigated; most of them were employees in light industry (58.2\%) or in public services (23.9\%). Past medical history was recorded and physical examination was performed. Questionnaires were used to characterize daily activity. Fasting venous blood sample was collected for measuring laboratory parameters. Data from shift workers ( $n=234$, age: $43.9 \pm 8.1$ years) were compared to those of daytime workers ( $n=247$, age: $42.8 \pm 8.5$ years), men and women were analyzed separately.

Results: In men, systolic blood pressure was higher in shift workers compared to daytime workers (133 \pm 8 vs $126 \pm$ $17 \mathrm{mmHg} ; \mathrm{p}<0.05)$. In women, weight (73.6 \pm 15.5 vs $67.7 \pm 13.2 \mathrm{~kg} ; \mathrm{p}<0.001)$, body mass index (27.5 \pm 5.7 vs $25.0 \pm$ $4.3 \mathrm{~kg} / \mathrm{m} 2 ; \mathrm{p}<0.001)$ and the prevalence rate of hypertension in the past medical history (24.4 vs $13.4 \% ; p<0.01$ ) were higher in shift workers compared to daytime workers. In addition, the proportion of current smokers was higher (37.7 vs 21.7\%; $p<0.001)$ and HDL-cholesterol level was lower $(1.56 \pm 0.32$ vs $1.68 \pm 0.36 \mathrm{mmol} / \mathrm{l} ; \mathrm{p}<0.01)$ in female shift workers than in female daytime workers. Both in men and in women, rotating shift workers spent less time sleeping both on working days and on non-working days, spent less time with sport activity, drank more coffee and they spent less time working per day, especially in light physical work, compared to daytime workers. In addition, low and middle educational levels were most frequently found among rotating shift workers as opposed to the daytime workers where high educational level was more common.
\end{abstract}

Conclusion: Middle-aged active shift workers, especially women, have a less healthy lifestyle and are at higher cardiometabolic risk as compared to daytime workers. Our study highlights the importance of measures for identifying and preventing cardiometabolic risk factors in shift workers.

Keywords: Cardiometabolic risk, Metabolic syndrome, Cardiovascular diseases, Circadian rhythm, Shift workers

\section{Background}

It is well known that several physiological functions follow a circadian rhythm, and it is also documented that longterm disturbance of the circadian rhythm have clinical consequences. Obviously, the circadian rhythm of long time shift workers may become disturbed. Accordingly, higher incidence of somatic diseases such as coronary heart disease [1], metabolic syndrome [2] as well as mental and behavioural disorders [3] or sleep disturbances [4] has been described among shift workers.

\footnotetext{
* Correspondence: gyjermendy@mail.datanet.hu

${ }^{1}$ Teaching Department of Medicine, Bajcsy-Zsilinszky Hospital, Maglódi út 8991, Budapest, 1106, Hungary

Full list of author information is available at the end of the article
}

Cardiovascular risk factors are taken into account in a wider aspect in the concept of cardiometabolic risk than in the metabolic syndrome $[5,6]$. The concept of cardiometabolic risk has become widely accepted in the literature after the debate on the metabolic syndrome [7]. In addition to waist circumference, blood pressure, HDLcholesterol, serum triglycerides and fasting blood glucose value, cardiometabolic risk include not only some other classical risk factors (age, gender, ethnicity, physical activity, smoking, LDL-cholesterol) but newer risk factors, such as CRP, as well. The identification of asymptomatic individuals with increased cardiometabolic risk has a great importance because it provides the basis of the primary prevention of cardiovascular diseases. Obviously,

\section{() Biomed Central}


early detection of the cardiometabolic risk factors can be achieved only by using screening methods among asymptomatic individuals.

In the present clinical study we examined the occurrence of cardiometabolic risk factors among active shift workers. The screening data of rotating shift (day/night) workers were compared to those of daytime workers.

\section{Patients and methods}

Workers registered in factory medical services were examined in the city of Györ, Hungary. Active workers between the ages of 25-66 years $(n=481$, men: 121 , women: 360) participated in the screening, 247 (men: 67, women: 180) worked in only daytime and 234 (men: 54 , women: 180) worked in rotating (day/night) shift. Employment for at least 5 years under the same daytime or day/night shift pattern was an inclusion criterion. The workers' distribution by workplace was as follows: light industry $58.2 \%$, public service $23.9 \%$, car industry $6.0 \%$, health care $1.0 \%$, transportation $0.4 \%$, food industry $0.4 \%$ and other $10.1 \%$.

The screening was performed on a voluntary basis following preliminary information about the study and a date selection. Using pre-printed questionnaires major events of medical history were recorded. In this way, diabetes, hypertension, cardiovascular diseases and abnormal lipids in the past medical history but not earlier than the beginning of the employment were registered. In addition, information on the nature of work (mental, light physical, heavy physical work), on the time spent with work and sleep, on sport activities, smoking, coffee consumption and level of education (low: primary school, middle: secondary school, high: university) was collected. Anthropometric data were recorded (weight, height, waist circumference), body mass index was calculated and blood pressure was measured by standard methods using mercury sphygmomanometers. This was followed by venous blood collection in fasting state; plasma glucose, LDL-cholesterol, HDL-cholesterol, triglycerides, serum creatinine and uric acid values were determined by standard laboratory methods. The measurements were performed on the day of the blood collection and at the same laboratory.

The study was conducted after obtaining the ethical approval from the ETT TUKEB (84-30/2007-1018EKU). All subjects gave their written informed consent prior to participation. The results of their screening were made available for the study subjects accompanied by medical advice if it was necessary.

During the statistical analysis for group comparisons for continuous variables the Mann-Whitney test, for categorical variables the Fisher's exact test were used. Data from men and women were analyzed separately; results of combined analysis (men + women) were not used for characterizing life style and working patterns. The data are presented as mean \pm standard deviation $(x \pm S D)$ or percentage (\%). The level of significance was set at $\mathrm{p}<0.05$.

\section{Results}

Mostly middle-aged subjects participated in the screening (mean age: $43.4 \pm 8.3$ years, range: $25-66$ years). There was no significant difference between the age of rotating shift workers and daytime workers $(43.9 \pm 8.1$ vs $42.8 \pm 8.5$ years) and no significant difference was observed between the age of men and women ( $42.4 \pm 9.1$ vs $43.7 \pm 8.1$ years). Both men and women have worked for several years (15.6 \pm 10.5 and $15.9 \pm 10.4$ years, respectively) without changes their working place and working patterns (daytime or day/night shift work).

In men, rotating shift workers spent less time sleeping both on working days and on non-working days, spent less time with sport activity, drank more coffee and they spent less time working per day, especially in light or heavy physical work, compared to daytime workers. Within the rotating male shift workers most frequently low and middle educational levels were found as opposed to the daytime workers where high educational level was more common (Table 1). As for the cardiometabolic risk factors, systolic blood pressure proved to be higher in male shift workers compared to daytime workers (Table 2).

In women, the duration of the employment was shorter in shift workers than that in daytime workers. Rotating female shift workers spent less time sleeping both on working days and on non-working days, spent less time with sport activity, drank more coffee, more were current smokers and they spent less time working per day, especially in light physical work, compared to daytime workers. Within the rotating female shift workers most frequently low and middle educational levels were found as opposed to the daytime workers where high educational level was more common (Table 1). Body weight, body mass index were found to be higher within the rotating shift female workers and hypertension was more common than within the daytime workers. From the laboratory data, the HDLcholesterol level was lower in women with rotating shifts than that of daytime workers (Table 2).

\section{Discussion}

Our data suggest that workers, especially women, in long-term rotating (day/night) shifts have a less healthy lifestyle and a less favourable cardiometabolic risk profile compared to daytime workers.

Several cross-sectional studies have shown that the cardiovascular risk profile of rotating shift (day/night) workers is disadvantageous compared to daytime workers. This could be consistently observed through a range 
Table 1 Daily activity and education levels in rotating (day/night) shift workers and daytime workers (men and women analyzed separately)

\begin{tabular}{|c|c|c|c|c|}
\hline & \multicolumn{2}{|l|}{ Men $(n=121)$} & \multicolumn{2}{|l|}{ Women $(n=360)$} \\
\hline & $\begin{array}{l}\text { Shift workers } \\
(\mathrm{n}=54)\end{array}$ & $\begin{array}{l}\text { Daytime workers } \\
(\mathrm{n}=67)\end{array}$ & $\begin{array}{l}\text { Shift workers } \\
(\mathrm{n}=180)\end{array}$ & $\begin{array}{l}\text { Daytime workers } \\
(\mathrm{n}=180)\end{array}$ \\
\hline Daily worktime (hours) & $8.44 \pm 1.42^{* *}$ & $8.67 \pm 1.29$ & $8.22 \pm 0.99^{* *}$ & $8.25 \pm 1.10$ \\
\hline Duration of employment (years) & $14.3 \pm 7.2$ & $16.6 \pm 12.6$ & $12.8 \pm 7.9^{* * *}$ & $19.0 \pm 11.6$ \\
\hline $\begin{array}{l}\text { Feature of work (\%) } \\
\text { mental/light physical/heavy physical }\end{array}$ & $1.8 / 84.9 / 13.3^{* * *}$ & $80.6 / 19.4 / 0$ & $0.6 / 97.7 / 1.7^{* * *}$ & $77.6 / 22.4 / 0$ \\
\hline Duration of sleeping in a workday (hours) & $6.3 \pm 0.9^{* *}$ & $6.9 \pm 0.9$ & $6.2 \pm 0.9^{* * *}$ & $7.0 \pm 1.1$ \\
\hline Duration of sleeping in a non-working day (hours) & $7.6 \pm 1.8^{* *}$ & $8.0 \pm 1.0$ & $7.6 \pm 1.1^{* * *}$ & $8.1 \pm 1.3$ \\
\hline $\begin{array}{l}\text { Sport activity } \\
\text { yes/no }(\%)\end{array}$ & $31.4 / 68.6$ & $46.3 / 53.7$ & $17.3 / 82.7^{* * *}$ & $35.9 / 64.1$ \\
\hline Weekly sport activity (min) & $44.0 \pm 95.6^{*}$ & $75.6 \pm 102.8$ & $21.9 \pm 66.6^{* * *}$ & $40.0 \pm 74.4$ \\
\hline $\begin{array}{l}\text { Smokers (\%) } \\
\text { never/ex smokers/current smokers }\end{array}$ & $57.5 / 16.6 / 25.9$ & $53.8 / 32.8 / 13.4$ & $46.1 / 16.1 / 37.8^{* * *}$ & $66.4 / 11.7 / 21.7$ \\
\hline $\begin{array}{l}\text { Coffee consumption } \\
\text { (dose/day) }\end{array}$ & $1.9 \pm 1.3^{* *}$ & $1.1 \pm 1.1$ & $1.9 \pm 1.2^{* *}$ & $1.6 \pm 1.3$ \\
\hline $\begin{array}{l}\text { Education level (\%) } \\
\text { low/middle/high }\end{array}$ & $12.9 / 85.2 / 1.9^{* * *}$ & $1.4 / 34.4 / 64.2$ & $22.9 / 76.6 / 0.5^{* * *}$ & 2.7/45.6/51.7 \\
\hline
\end{tabular}

${ }^{*} p<0.05{ }^{* *} p<0.01{ }^{* * *} p<0.001$ (shift workers versus daytime workers; men and women analyzed separately)

of different employments (police officers, road builders, factory workers, nurses) [8-11]. In a recently published meta-analysis the relationship between rotating shift work and the incidence of ischemic heart disease was examined and indicators of morbidity rather than mortality data were found to be influenced by rotating shift work [12]. Some studies have analyzed the prevalence rate of the metabolic syndrome, and an increase was observed among rotating shift ( $v s$. daytime) workers $[13,14]$. Others have reported on the more frequent occurrence of the individual components of the metabolic syndrome (hypertension, diabetes, lipid abnormalities, obesity) $[9,10,15-18]$. The results of the crosssectional observations have also been confirmed by

Table 2 Clinical and laboratory findings in rotating (day/night) shift workers and daytime workers (men and women analyzed separately)

\begin{tabular}{|c|c|c|c|c|}
\hline & \multicolumn{2}{|l|}{ Men $(n=121)$} & \multicolumn{2}{|c|}{ Women $(n=360)$} \\
\hline & $\begin{array}{l}\text { Shift workers } \\
(\mathrm{n}=54)\end{array}$ & $\begin{array}{l}\text { Daytime workers } \\
(\mathrm{n}=67)\end{array}$ & $\begin{array}{l}\text { Shift workers } \\
(n=180)\end{array}$ & $\begin{array}{l}\text { Daytime workers } \\
(\mathrm{n}=180)\end{array}$ \\
\hline Age (years) & $42.2 \pm 8.1$ & $42.5 \pm 9.8$ & $44.5 \pm 8.1$ & $42.9 \pm 8.0$ \\
\hline Weight (kg) & $86.5 \pm 14.1$ & $90.4 \pm 17.6$ & $73.6 \pm 15.5^{* * *}$ & $67.7 \pm 13.2$ \\
\hline BMI $\left(\mathrm{kg} / \mathrm{m}^{2}\right)$ & $27.3 \pm 3.9$ & $28.7 \pm 5.5$ & $27.5 \pm 5.7^{* * *}$ & $25.0 \pm 4.3$ \\
\hline Waist circumference $(\mathrm{cm})$ & $96.9 \pm 10.9$ & $101.1 \pm 13.2$ & $92.0 \pm 13.5$ & $89.2 \pm 11.9$ \\
\hline Systolic blood pressure $(\mathrm{mmHg})$ & $133 \pm 18^{*}$ & $126 \pm 17$ & $121 \pm 19$ & $117 \pm 15$ \\
\hline Diastolic blood pressure $(\mathrm{mmHg})$ & $79 \pm 10$ & $79 \pm 11$ & $75 \pm 11$ & $74 \pm 10$ \\
\hline Diabetes in the past medical history (\%) & 3.7 & 1.4 & 4.7 & 1.1 \\
\hline Hypertension in the past medical history (\%) & 14.4 & 23.8 & $24.4^{* *}$ & 13.4 \\
\hline CV diseases in the past medical history (\%) & 1.8 & 0.0 & 4.4 & 1.1 \\
\hline Abnormal lipids in the past medical history (\%) & 5.5 & 7.4 & 7.2 & 6.1 \\
\hline $\begin{array}{l}\text { Fasting blood glucose } \\
(\mathrm{mmol} / \mathrm{l})\end{array}$ & $4.87 \pm 1.39$ & $4.91 \pm 1.16$ & $4.73 \pm 0.89$ & $4.56 \pm 0.60$ \\
\hline Serum LDL-cholesterol (mmol/l) & $3.42 \pm 0.88$ & $3.70 \pm 0.79$ & $3.50 \pm 1.01$ & $3.46 \pm 0.84$ \\
\hline $\begin{array}{l}\text { Serum triglycerides } \\
(\mathrm{mmol} / \mathrm{l})\end{array}$ & $1.87 \pm 1.33$ & $2.18 \pm 1.60$ & $1.28 \pm 0.69$ & $1.30 \pm 0.68$ \\
\hline $\begin{array}{l}\text { Serum uric acid } \\
(\mu \mathrm{mol} / \mathrm{l})\end{array}$ & $343 \pm 66$ & $336 \pm 70$ & $265 \pm 69$ & $262 \pm 57$ \\
\hline Serum HDL-cholesterol ( $\mathrm{mmol} / \mathrm{l})$ & $1.34 \pm 0.36$ & $1.31 \pm 0.35$ & $1.56 \pm 0.32^{* *}$ & $1.68 \pm 0.36$ \\
\hline $\begin{array}{l}\text { Serum creatinine } \\
(\mu \mathrm{mol} / \mathrm{l})\end{array}$ & $83 \pm 10$ & $83 \pm 11$ & $66 \pm 9$ & $65 \pm 9$ \\
\hline
\end{tabular}


recent follow-up studies [11,19]. Our data - the first observation from Hungary - are consistent with the results of studies published previously.

Although our study cannot be considered representative, the results should be frustrating, especially if one takes into account how many employees may work in shifts. Reliable national statistics are not available in this area, but according to data from industrial countries approximately $20 \%$ of the active employees work in rotating or nightshifts [20].

Our cross-sectional study could not provide data about the possible reasons for the increased cardiometabolic risk of shift workers. According to the generally accepted theory the human circadian biological rhythm is controlled by the neural network of the suprachiasmatic nuclei of the hypothalamus [21]. Certain polymorphisms of the nuclear genes involved in the regulation (CLOCK: circadian locomotor output cycles kaput, BMAL1/ARNTL: brain and muscle aryl-hydrocarbon receptor nuclear translocator-like 1/aryl-hydrocarbon receptor nuclear translocator-like, NPAS2: neuronal PAS domain protein 2) have been shown to be associated with increased body weight and the disruption of circadian rhythm. However, the physiological circadian rhythm can also be damaged due to external factors, which include long-term rotating shift work (21). Due to the disturbance of the circadian rhythm mood disorders (depression), sleep disorders and also an increase in cardiometabolic risk may develop [22,23] (Figure 1). Recent data suggest that melatonin also has a regulatory role [24], as it has been demonstrated that the presence of one of its gene polymorphisms (MTNR1b) increases the risk of developing type 2 diabetes mellitus [25].

In our cohort the rotating shift workers (compared to daytime workers) slept less, both on working days and on non-working days. We do not have data on the quality of sleep. It is typical of industrial countries that in

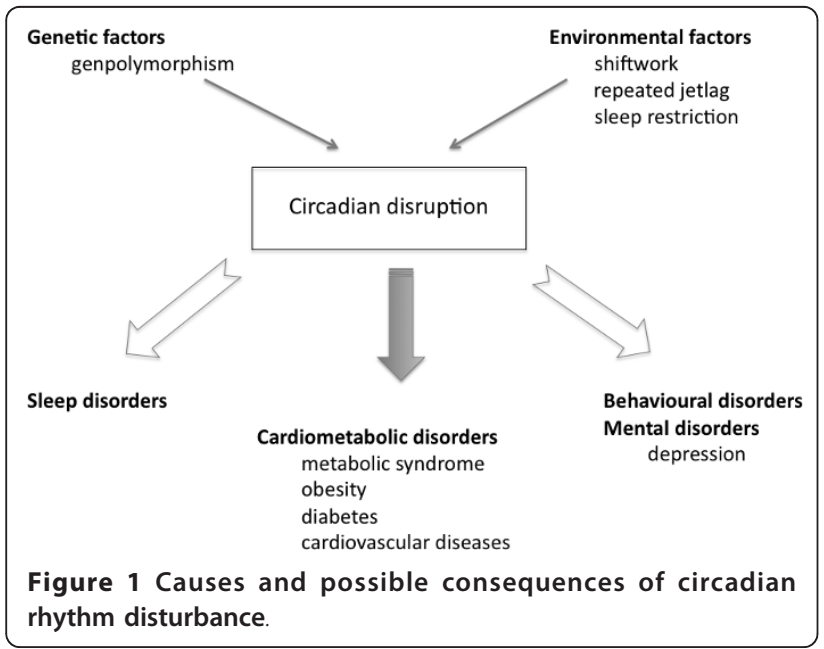

recent years sleep duration has become shorter. More than one-third of the adult population in the United States sleep less than 6 hours per night, and over the past 40 years daily sleeping time has decreased by nearly 2 hours [26]. Sleep deprivation, according to a clinical study, has resulted in an increase in fasting blood glucose and a decrease in insulin sensitivity [27]. During sleep deprivation serum leptin levels were found to be lower, ghrelin levels higher, appetite and consumption of carbohydrate containing foods increased [28]. Another study found increased resistin levels in shift workers [29]. All these alterations can lead to an increase in body weight.

Sleep deprivation and the disruption of circadian rhythm may result in an increase in blood pressure [30] and in a higher incidence of type 2 diabetes mellitus [31] and cardiovascular diseases [32]. A meta-analysis showed that rotating shift work increased the risk of cardiovascular disease by $40 \%$ [33]. The increase in body weight is a common phenomenon among rotating shift workers [34]. Data suggestive of these facts have also been provided by our current study. More frequent smoking and less time spent with physical activity among rotating shift workers found in our study are also in accordance with results from other investigations [12].

Among the rotating shift workers most frequently low and middle education levels were found, while in the daytime worker group high education levels were more prevalent. The lower level of education is associated with a more frequent prevalence of the metabolic syndrome or its individual components [35]. This may play a role in the unfavourable cardiometabolic risk profile of shift workers compared to that of daytime workers.

Our study has some limitations. The study design was cross-sectional in nature. The investigation was carried out on a voluntary basis following preliminary information about the study. Participants worked in different working place but mainly in light industry; subgroup analysis according to working places could not be performed due to sample size. Consequently, differences between white-collar and blue-collar workers could not be evaluated. Bearing in mind all these limitations, our data - the first observation from Hungary - should be of interest. It is obvious that recognition and treatment of cardiovascular risk is an important area of the primary and secondary medical care. Appropriate screening for identification of individuals at risk may become the basis of the implementation of primary prevention.

\section{Conclusion}

Our data indicate that middle-aged active shift workers, especially women, have a less healthy lifestyle and are at higher cardiometabolic risk as compared to daytime 
workers. Therefore, measures for identifying and preventing cardiometabolic risk factors in shift workers are of great importance.

\section{Acknowledgements}

The study was sponsored by the Hungarian Diabetes Association. We are grateful for László Szakács (Planiméter Ltd.) for performing the statistical analysis.

Parts of this study were presented as an abstract form (poster presentation) at the $70^{\text {th }}$ Annual Meeting of the American Diabetes Association (Orlando, FI, USA, 25-29, June, 2010).

\section{Author details}

'Teaching Department of Medicine, Bajcsy-Zsilinszky Hospital, Maglódi út 8991, Budapest, 1106, Hungary. ${ }^{2}$ Kardirex Medical Center, Táncsics út 43, Györ, 9024, Hungary. ${ }^{3}$ Department of Medicine, Petz Teaching Hospital, Vasvári út 2-4, Györ, 9024, Hungary

\section{Authors' contributions}

GJ conceived of the study, participated in its design and coordination, supervised the statistical analysis and wrote the final manuscript. NJ, IH, IV participated in data collection. TH participated in designing and coordinating the study and revised the manuscript. All authors read and approved the finale manuscript.

\section{Competing interests}

The authors declare that they have no competing interests.

Received: 8 July 2011 Accepted: 1 February 2012

Published: 1 February 2012

\section{References}

1. Fujino $Y$, Iso H, Tamakoshi A, Inaba Y, Koizumi A, Kubo T, Yoshimura T, Japanese Collaborative Cohort Study Group: A prospective cohort study of shift work and risk of ischemic heart disease in Japanese male workers. Am J Epidemiol 2006, 164:128-135.

2. Karlsson B, Knutsson A, Lindahl B: Is there an association between shift work and having a metabolic syndrome? Results from a population based study of 27,485 people. Occup Environ Med 2001, 58:747-752.

3. Woo JM, Postolache TT: The impact of work environment on mood disorders and suicide: Evidence and implications. Int J Disabil Hum Dev 2008, 7:185-200.

4. Ohayon MM, Lemoine P, Arnaud-Briant V, Dreyfus M: Prevalence and consequences of sleep disorders in a shift worker population. $J$ Psychosom Res 2002, 53:577-583.

5. Després JP, Lemieux I: Abdominal obesity and metabolic syndrome. Nature 2006, 444:881-887.

6. Després JP, Cartier A, Côté M, Arsenault BJ: The concept of cardiometabolic risk: Bridging the fields of diabetology and cardiology. Ann Med 2008, 40:514-523.

7. Borch-Johnsen $\mathrm{K}$, Wareham N: The rise and fall of the metabolic syndrome. Diabetologia 2010, 53:597-599.

8. Violanti JM, Burchfiel CM, Hartley TA, Mnatsakanova A, Fekedulegn D, Andrew ME, Charles LE, Vila BJ: Atypical work hours and metabolic syndrome among police officers. Arch Environ Occup Health 2009, 64:194-201.

9. Morikawa Y, Nakagawa H, Miura K, Soyama Y, Ishizaki M, Kido T, Naruse Y, Suwazono Y, Nogawa K: Shift work and the risk of diabetes mellitus among Japanese male factory workers. Scand J Work Environ Health 2005, 31:179-183.

10. Ghiasvand M, Heshmat R, Golpira R, Haghpanah V, Soleimani A, Shoushtarizadeh P, Tavangar SM, Larijani B: Shift working and risk of lipid disorders: a cross-sectional study. Lipids Health Dis 2006, 10(5):9.

11. Pietroiusti A, Neri A, Somma G, Coppeta L, lavicoli I, Bergamaschi A, Magrini A: Incidence of metabolic syndrome among night-shift healthcare workers. Occup Environ Med 2010, 67:54-57.

12. Frost P, Kolstad HA, Bonde JP: Shift work and the risk of ischemic heart disease - a systematic review of the epidemiologic evidence. Scand J Work Environ Health 2009, 35:163-179.
13. Esquirol Y, Bongard V, Mabile L, Jonnier B, Soulat JM, Perret B: Shift work and metabolic syndrome: respective impacts of job strain, physical activity, and dietary rhythms. Chronobiol Int 2009, 26:544-559.

14. Sookoian S, Gemma C, Fernández Gianotti T, Burgueño A, Alvarez A, González CD, Pirola CJ: Effects of rotating shift work on biomarkers of metabolic syndrome and inflammation. J Intern Med 2007, 261:285-292.

15. Nazri SM, Tengku MA, Winn T: The association of shift work and hypertension among male factory workers in Kota Bharu, Kelantan, Malaysia. Southeast Asian J Trop Med Public Health 2008, 39:176-183.

16. Di Lorenzo L, De Pergola G, Zocchetti C, L'Abbate N, Basso A, Pannacciulli N, Cignarelli M, Giorgino R, Soleo L: Effect of shift work on body mass index: results of a study performed in 319 glucose-tolerant men working in a Southern Italian industry. Int I Obes Relat Metab Disord 2003, 27:1353-1358.

17. Antunes LC, Levandovski R, Dantas G, Caumo W, Hidalgo MP: Obesity and shift work: chronobiological aspects. Nutr Res Rev 2010, 23:155-168.

18. Antunes LC, da Jornada MN, Ramalho L, Hidalgo MP: Correlation of shift work and waist circumference, body mass index, chronotype and depressive symptoms. Ara Bras Endocrinol Metabol 2010, 54:652-656.

19. De Bacquer D, Van Risseghem M, Clays E, Kittel F, De Backer G, Braeckman L: Rotating shift work and the metabolic syndrome: a prospective study. Int J Epidemiol 2009, 38:848-854.

20. Eastman Cl, Boulos Z, Terman M, Campbell SS, Dijk DJ, Lewy AJ: Light treatment for sleep disorders: consensus report. VI. Shift work. J Biol Rhythms 1995, 10:157-164.

21. Duez $H$, Staels B: Nuclear receptors linking circadian rhythms and cardiometabolic control. Arterioscler Thromb Vasc Biol 2010, 30:1529-1534.

22. Maury E, Ramsey KM, Bass J: Circadian rhythms and metabolic syndrome. From experimental genetics to human disease. Circ Res 2010, 106:447-462.

23. Puttonen $S$, Harma M, Hublin C: Shift work and cardiovascular disease pathways from circadian stress to morbidity. Scand I Work Environ Health 2010, 36:96-108.

24. Cardinali DP, Cano P, Jiménez-Ortega V, Esquifino Al: Melatonin and the metabolic syndrome: physiopathologic and therapeutical implications. Neuroendocrinology 2011, 93:133-142.

25. Bouatia-Naji N, Bonnefond A, Cavalcanti-Proença C, Sparsø T, Holmkvist J, Marchand M, Delplanque J, Lobbens S, Rocheleau G, Durand E, De Graeve F, Chèvre JC, Borch-Johnsen K, Hartikainen AL, Ruokonen A, Tichet J, Marre M, Weill J, Heude B, Tauber M, Lemaire K, Schuit F, Elliott P, Jørgensen T, Charpentier G, Hadjadj S, Cauchi S, Vaxillaire M, Sladek R, Visvikis-Siest S, Balkau B, Lévy-Marchal C, Pattou F, Meyre D, Blakemore Al, Jarvelin MR, Walley AJ, Hansen T, Dina C, Pedersen O, Froguel P: A variant near MTNR1B is associated with increased fasting plasma glucose levels and type 2 diabetes risk. Nat Genet 2009, 41:89-94.

26. Pamidi S, Aronsohn RS, Tasali E: Obstructive sleep apnea: role in the risk and severity of diabetes. Best Pract Res Clin Endocrinol Metab 2010, 24:703-715.

27. González-Ortiz M, Martínez-Abundis E, Balcázar-Muñoz BR, PascoeGonzález S: Effect of sleep deprivation on insulin sensitivity and cortisol concentration in healthy subjects. Diabetes Nutr Metab 2000, 13:80-83.

28. Spiegel K, Tasali E, Penev P, Van Cauter E: Sleep curtailment in healthy young men is associated with decreased leptin levels, elevated ghrelin levels, and increased hunger and appetite. Ann Intern Med 2004, 141:846-850

29. Burgueño A, Gemma C, Gianotti TF, Sookoian S, Pirola CJ: Increased levels of resistin in rotating shift workers: a potential mediator of cardiovascular risk associated with circadian misalignment. Atherosclerosis 2010, 210:625-629

30. Suwazono Y, Dochi M, Sakata K, Okubo Y, Oishi M, Tanaka K, Kobayashi E, Nogawa K: Shift work is a risk factor for increased blood pressure in Japanese men: a 14-year historical cohort study. Hypertension 2008, 52:581-586.

31. Kroenke CH, Spiegelman D, Manson J, Schernhammer ES, Colditz GA, Kawachi I: Work characteristics and incidence of type 2 diabetes in women. Am J Epidemiol 2007, 165:175-183.

32. Kawachi I, Colditz GA, Stampfer MJ, Willett WC, Manson JE, Speizer FE, Hennekens CH: Prospective study of shift work and risk of coronary heart disease in women. Circulation 1995, 92:3178-3182.

33. Bøggild H, Knutsson A: Shift work, risk factors and cardiovascular disease. Scand J Work Environ Health 1999, 25:85-99. 
34. Cappuccio FP, Taggart FM, Kandala NB, Currie A, Peile E, Stranges S, Miller MA: Meta-analysis of short sleep duration and obesity in children and adults. Sleep 2008, 31:619-626.

35. Hidvégi T, Hetyési K, Bíró L, Jermendy G: Education level and clustering of clinical characteristics of metabolic syndrome. Diabetes Care 2001, 24:2013-2014

\section{doi:10.1186/1477-7525-10-18}

Cite this article as: Jermendy et al: Assessment of cardiometabolic risk among shift workers in Hungary. Health and Quality of Life Outcomes 2012 10:18.

Submit your next manuscript to BioMed Central and take full advantage of:

- Convenient online submission

- Thorough peer review

- No space constraints or color figure charges

- Immediate publication on acceptance

- Inclusion in PubMed, CAS, Scopus and Google Scholar

- Research which is freely available for redistribution 